\title{
Article \\ Leopold Cohn and the Evolution of Messianic Judaism into the Leading Missionary Movement among American Jews ${ }^{\dagger}$
}

\author{
Menachem Keren-Kratz
}

check for updates

Citation: Keren-Kratz, Menachem. 2022. Leopold Cohn and the

Evolution of Messianic Judaism into the Leading Missionary Movement among American Jews. Religions 13: 104. https://doi.org/10.3390/ rel13020104

Academic Editor: Jeff Levin

Received: 19 December 2021

Accepted: 10 January 2022

Published: 21 January 2022

Publisher's Note: MDPI stays neutral with regard to jurisdictional claims in published maps and institutional affiliations.

Copyright: (c) 2022 by the author. Licensee MDPI, Basel, Switzerland. This article is an open access article distributed under the terms and conditions of the Creative Commons Attribution (CC BY) license (https:// creativecommons.org/licenses/by/ $4.0 /)$.
Independent Researcher, Ramat Hasharon 4704351, Israel; menachem.keren.kratz@gmail.com

+ This article is based on lectures given at Columbia University's seminar of Studies in Religions; the 35th Annual Meeting of the Association for Israel Studies; and at The Chosen People Ministries conference celebrating its 125th anniversary. The lecture at CPM's conference, which was tailored for the specific audience of Messianic Jews, was later published in their journal.

\begin{abstract}
Since the early days of Christianity, it was generally accepted that a person could be either a Jew or a Christian, but not both. This, however, changed in the late nineteenth century. Yitzhak Leib Josowitz was a young Jew who studied at Hungary's top yeshivas and ordained as a rabbi. Shortly after settling in New York in 1892, he converted, ordained a priest, changed his name to Leopold Cohn, and became a missionary. Cohn promoted a relatively new missionary approach which encouraged Jews to retain their identity and traditions, but also to adopt Jesus as their messiah. This, he claimed, would not only make them better Jews, but would also win them a higher spiritual status than people who were born Christians. Cohn also convinced many Christians to donate to his mission, which he called The Chosen People. After his death in 1937 Leopold was succeeded by his son Joseph, who greatly expanded the mission's outreach. In time the missionary approach Cohn developed was adopted by other missions and became known as Messianic Judaism. Today, the dozens of messianic missions have millions of members and one of the most active ones is Cohn's Chosen People which continue its operation more than 125 years after its establishment.
\end{abstract}

Keywords: Messianic Judaism; Mission to the Jews; Chosen Pepole Ministries; Jewish-Christian relations; Evangelical Christianity

\section{Introduction}

Although Jews have settled in America since the early seventeenth century, the protestant church began to evangelize them only in 1816. Two years later, by 1818 , the number of American Jews reached 3000. Thirty years later, in 1848, their number reached 50,000, and by 1888 there were already 400,000 Jews in America. ${ }^{1}$ As their numbers continued to grow, so did the motivation of the various churches to proselytize the Jews.

One of the prominent missionaries in the mid-nineteenth century was Gideon Lederer. He was a Hungarian Jew who was educated in top yeshivas, ordained as a rabbi, and later converted to Christianity. After arriving in America in 1854, he became a missionary who encouraged Jews to believe in Jesus in order to fully materialize their Jewish identity. Between 1857-1865 he published The Israelite Indeed, a journal that promoted his messianic ideas (Sarna 1980). A second missionary with a Jewish Hungarian background, who also supported messianic ideas, was Charles Freshman, who operated in Canada (Freshman 1868). Another missionary in that period to promote the concept of Messianic Judaism was Arno C. Gaebelein, who, unlike the former two, was a born Christian (Rausch 1983).

Yet, as scholar Yaakov Ariel asserts: "Until the 1880s, however, the missionary enterprises were small and sporadic [ ... ] In the late 1870s, only one mission labored among the Jews in America" (Ariel 2000, p. 2). Later on, however, the number of missions targeting the Jews rose significantly and dozens of missions still operate to this day (Meyer 1983; Åna and Kvalbein 2000; Mégier 2008; Stratton and Lieber 2016). 
The rise in missionary activity in America since the late-nineteenth century can be attributed to three factors: A. The great Jewish migration period between the early $1880 \mathrm{~s}$ and the early 1920s, during which the number of Jews grew tenfold, and by 1927 they already numbered over 4.2 million. B. The spreading of Dispensationalism, the school of Christian premillennialist eschatology that was founded in Britain in the 1830s and gained popularity in the United States since the 1870s. In addition, $\mathrm{C}$. the rise of Jewish nationalism since the mid-nineteenth century that culminated in the establishment of the Zionist movement in 1897 (Brog and Hagee 2006).

Dispensationalism claims that the Bible is God's literal Word of His plan for history and should be interpreted both literally and historically. Among other things, it sets God's plan for the end of times and defines the various stages before the second coming of Jesus. One necessary step in that process is the return of the Jews to the land of Israel. In the words of theologian Thomas Ice: "This plan for Israel includes promises that they will have the land of Israel, will have a seed, and will be a worldwide blessing to the nations" (Ice 2009). There is thus no wonder that premillennialist Dispensationalism gained so much popularity following the rise in Jewish nationalism in the late nineteenth century, which corresponded with what it conceived as the Godly scheme (Brog and Hagee 2006, pp. 42-46). This raised the interest of Christians in their Jewish neighbors. Ariel explains:

Before that time mainline Protestant churches had not yet embraced the premillennialist messianic belief, which usually brought with it in increased interest in the Jews and the prospect of their conversion and national restoration [ ... ] prior to the 1880s, evangelizing the Jews was not a high priority for American protestants, especially when compared to the support they gave this work from that time onwards. (Ariel 2000, p. 4)

Since Jews, who denied and condemned Jesus, were perceived as bad and mistaken, and since according to premillennialist eschatology they still had a crucial role to play, a new sort of mission was invented in the early nineteenth century. Protestant missions in England and Scotland no longer sought to fully convert the Jews, but rather encouraged them to preserve their Jewish identity while at the same time accepting Jesus Christ as their savior and the New Testament as their additional Bible. These converts were known initially as Christian Jews and this type of mission was later known as Messianic Judaism. In Europe, Messianic Judaism failed to gain much ground, and it appears that there were no more than a few hundred Christian Jews in the whole continent (Gidney 1908; Popkin 1994; Nerel 1996, pp. 24-36). In America, however, since the late nineteenth century Messianic Judaism has become the leading type of mission to the Jews (Sobel 1974; Cohn-Sherbok 2000). Today, these messianic missions have millions of members worldwide, including several tens of thousands of Jews. This development can be attributed to the work of one person: Eisik Leib Yosowitz, later known as Leopold Cohn.

Cohn, moreover, is also among those early religious leaders, such as William $H$. Hechler and William E. Blackstone, who changed the way Christians regarded Jews in general and Jewish nationalism in particular. Until the late nineteenth century, almost all Christian leaders considered Jews complete sinners and heretics worthy of hatred and discrimination. Since the twentieth century, however, an increasing number of Christian ministers, most of whom have been evangelical protestant, called their congregants to treat Jews with much respect and to fully support their national demands over the land of Israel, namely the State of Israel (Brog and Hagee 2006, pp. 91-106).

This article reviews one of the most successful missions to operate among Jews, The Chosen People, which was founded by Leopold Cohn in the 1890s. This mission, now titled The Chosen People Ministries (CPM), is still very active today, more than 125 years after its establishment (Glaser et al. 2021).

For a long time, the world has been puzzled by the discrepancy between great spiritual, cultural, and religious ideas as well as by the fact that at times the people which conceived them turned out to be unworthy, despicable, or liars. This is the case with Cohn as well. In this article, as is evident by its sources, I chose to bring this dichotomy to the fore rather than 
to conceal it. Consequently, while a majority of the sources are those supporting Cohn's side, others represent his many opponents' views. The fact that Cohn's mission survived for such a long time demonstrates that the virtue of his ideas surpassed the long-forgotten blemishes of his questionable personality.

\section{Eisik Leib Yosowitz's Life in Hungary}

Eisik Leib (in Hebrew: Yitzhak Ar'ye) Yosowitz was born in 1862 in the village of Brezna in the Maramaros county of eastern Hungary (Cohn 1996; Ariel 2000, pp. 28-29). ${ }^{2}$ This was a remote and sparsely populated region, most of whose inhabitants, including the Jews, were indigent farmers. The Jews of this region were known for their strong religious belief, their Hasidic lifestyle, and their absolute compliance with their rabbis' commands. Like most of the region's Jewish children, Eisik Leib grew up in a Yiddishspeaking, ultra-Orthodox environment and received a traditional Jewish education. This included acquiring the basic Hebrew reading and writing skills necessary for the study of selected sections of the Bible and an elementary study of the Talmud. Some of the boys were then sent to further their studies in a yeshiva-an institution of higher education dedicated solely to Talmudic studies (Gross and Cohen 1983, pp. 75-76; Keren-Kratz 2021).

When Eisik Leib was seven years old his father died, and after his bar mitzvah his mother sent him to the Hasidic yeshiva in Sighet, the county's capital. Rabbi Yekuthiel Yehuda Teitelbaum, the head of the yeshiva and the town's chief rabbi, was a Hasidic leader renowned for his zealous outlook. A few years later, Yosowitz continued his studies in Hungary's most prestigious yeshiva, located in Pressburg, today Bratislava, the capital of Slovakia. There, according to his own testimony, he was ordained as a rabbi (Cohn 1996, pp. 4-7; Bacon 1918, pp. 9-10). This claim, however, seems questionable, since according to the same testimony he did not spend sufficient time studying at the Pressburg yeshiva, nor was he married, two necessary conditions for becoming a rabbi. Moreover, even after concluding his studies and marrying, he failed to gain a rabbinical appointment, neither in his own village nor anywhere else (Bacon 1918, pp. 64-66).

After returning home, Yosowitz married Rosa Hoffman, the daughter of a prosperous Jew from Apshitza, another small village in Maramaros, and the couple went to live with the bride's parents. As was customary in those days if the groom was a Torah scholar, the bride's father would support the newlyweds, allowing the groom to continue his studies free of the need to provide for his wife. Unfortunately, the bride's father died a year later, obliging Yosowitz to assume responsibility for the family business and the management of the local inn that they owned. Given his considerable Talmudic knowledge, even though he held no formal position, the local Jews regarded him as a sort of unofficial rabbi, consulting him on all religious matters.

In 1891, Yosowitz and his brother-in-law were accused of forging a deed to a piece of land belonging to one of their clients who had passed away leaving no heir. Yosowitz immediately fled the country, leaving behind his wife and their four children: Benjamin, Joseph, Joshua, and Esther. He reached the United States after a lengthy journey and was warmly received by some of his friends and countrymen. Cohn later denied this version of events, claiming that he decided to emigrate to America on the advice of a Hungarian rabbi, whom he consulted when he began to entertain thoughts about Jesus being the Jewish messiah (Cohn 1996, pp. 9-10).

\section{The First Year in America}

Yosowitz claimed that after his arrival in New York in 1892 he sought the help of Rabbi Philip (Hillel) Klein, who had emigrated to America the previous year. Rabbi Klein, a prominent Jewish figure who headed Ohab Zedek, the largest Orthodox community of Hungarian Jews in New York, was, however, unable to help him obtain the rabbinical position he sought (Bacon 1918, pp. 11-14). ${ }^{3}$ Later, during one of Cohn's trials, Rabbi Klein denied ever meeting Yosowitz (Bacon 1918, pp. 58-60). 
Shortly thereafter, Yosowitz met Herman Warszaviak, a Polish Jewish immigrant who had converted and become a successful missionary (Douglas 1894). Warszaviak convinced Yosowitz to follow in his footsteps, and on 26 June 1892 Yosowitz converted. Following his conversion, Warszaviak helped Yosowitz obtain a scholarship to a Christian institution in Edinburgh, Scotland. While Yosowitz was on his way to Scotland, the news of his conversion reached his family in Hungary. They condemned him in the strongest terms and have shunned him ever since. Nevertheless, Yosowitz convinced his wife, who was devastated by his conversion, to join him with their children, and eventually they too converted (Cohn 1996, pp. 10-30; Bacon 1918, pp. 15-17). He excelled in his studies and was ordained a Baptist pastor. After returning to New York in October 1893, Eisik Leib Yosowitz changed his name to Leopold Cohn, presenting himself as a former Jewish rabbi. ${ }^{4}$ Despite numerous testimonies, including those made in court by his own family members, Cohn denied ever having borne the family name of Yosowitz.

A few weeks later, Cohn established his own mission in Brownsville, naming it The Chosen People. In those days, Brownsville comprised one of the largest concentrations of Jewish immigrants, most of whom lived in dire poverty and were victims of discrimination (Pollack 2013). ${ }^{5}$ Shortly thereafter, a Jew named Adolf Benjamin published a report on Cohn's dubious past in the local Jewish newspaper. ${ }^{6}$ Despite the negative publicity, Cohn won the trust of the Brooklyn chapter of the American Baptist Home Mission Society, which provided him with financial support. Since several missions were targeting New York's Jews at the time, Cohn needed to devise his own distinctive strategy (Cohn 1996, pp. 30-32; Tompson 1902, pp. 246-47; Bacon 1918, p. 17; Ariel 2000, pp. 29-30).

He did this in two ways. First, he adopted and expanded the idea of Messianic Judaism, which he had probably encountered in Europe and preferred to "regular" conversion. Second, he divided his resources, investing as much time and energy into preaching and working among Christians, whom he persuaded to contribute both time and money, as he did among Jews (Ariel 2000, p. 33). ${ }^{7}$

In time, Cohn's missionary station offered the same aid services as did other Christian and Jewish organization to new immigrants. His mission offered medical consultation and supplied used clothes and food packages donated by his Christian supporters. It also offered English-language classes and opened a sewing school where unskilled Jewish women were trained, enabling them to find work in the garment industry's sweatshops. This was virtually the only place where an uneducated woman who did not speak English could find work (Cohn 1996, pp. 32-41). ${ }^{8}$

Cohn invited Jews to celebrate the Sabbath and the Jewish holidays in a traditional atmosphere. Thanks to his rabbinical knowledge and to the fact that Yiddish was his mother tongue, he delivered sermons that to the uninitiated ears of the newcomers sounded like the ones they were used to hearing in the synagogue in their old homeland. Having captured the attention of his audience, he gradually incorporated his messianic message into his sermons. Unlike other missionaries, who persuaded Jews to abandon their Jewish legacy and replace it with Christian traditions and values, he urged his listeners to embrace belief in Christ as a full realization of their Jewish identity.

Cohn devoted much of his time and energy to creating strong links with the Christian community. In late 1895, he began publishing The Chosen People magazine, which he used as a vehicle for reporting to his Christian readers about his activities and persuading them to contribute money and volunteer in his mission (Cohn 1996, pp. 46-47). This became such a crucial tool in the mission's ongoing operation that despite the various changes to the mission's name and its numerous shifts in leadership, this monthly publication still appears today under the same title, more than 120 years after it was first published.

The magazine was intended for Christian readers, who were asked not to share it with Jews. ${ }^{9}$ The Chosen People appeared in a regular format. The first section provided updates on the mission's ongoing issues, such as large donations, the purchase of property, upcoming events, or important meetings. The next section reported on various events that took place in the mission, such as the arrival of visitors and the questions they asked, or confrontations 
with religious Jews. This might be followed by the story of a converted Jew, sometimes accompanied by their picture. The final section contained an account of the daily activities, such as those of the sewing school, or medical activities and other voluntary work. The last page was dedicated to a list of donors to the mission and their donations amounts.

In 1896, Cohn published his first book in Yiddish, entitled What Is His Name and What is His Son's Name (Cohn 1896). In the ensuing years he published several other books in Hebrew, Yiddish, and English, including Messiah Be Cut Off and Behold the Virgin (Cohn 1898a, 1898b).

The Jewish and Christian missionaries who preceded him regarded Jews as traitors and sinners and as inferior to Christians. Consequently, they encouraged Jews to relinquish their lesser status by embracing the superiority of Christianity. Cohn, on the contrary, regarded the Jews as the chosen people, as reflected in the name he chose for his mission. He exhorted Jews to retain their Jewish identity, while also acknowledging Christ as the true messiah and the New Testament as a direct continuation of the Old.

To his Christian audience, he explained that Messianic Jews possess an even loftier spiritual value than natural-born Christians, given their closer resemblance to Jesus who was also born a Jew. He proceeded to argue that only a converted Jewish rabbi, such as himself, could convince other Jews to adopt Jesus. Cohn was considered a great orator, and although he managed to convert only a relatively small number of Jews, he was able to persuade many Christians to support his work (Freuder 1915, p. 173; Ariel 2000, pp. 30-31).

\section{Expanding the Mission's Reach}

In 1897, Cohn opened another branch on one of Williamsburg's main streets, naming it the Williamsburg Mission to the Jews (Cohn 1996, pp. 41-43)..$^{10}$ This neighborhood was home to many former Hungarian Orthodox Jews who had moved there from Manhattan's Lower East Side. This soon became The Chosen People's most active station, and some fifteen years later, by the turn of the twentieth century, the Williamsburg Mission was considered one of the most successful missions operating among Jews in all of America. ${ }^{11}$

Over the years, the mission expanded its activities. By the early 1900s, on top of its regular activities, it offered recreational activities for boys and girls, allowing their mothers to go out to work. It also offered medical services, provided by doctors and nurses who worked in the clinic established by Cohn or visited the sick in their homes. ${ }^{12}$

Cohn's success won him many supporters, but also made him many enemies. He became notorious among Jews and also among some Christians, who saw him as a charlatan and an exploiter. Jewish leaders, however, found it difficult to take effective action against Cohn's mission because in Christian America-which harbored some antisemitic bias-messianic activity among the Jews was considered legitimate and even welcome (Sarna 1981; Ariel 2004). ${ }^{13}$

Cohn complained that on several occasions his workers faced threats and violent attacks. Yet, because the overall number of Jews who actually converted remained low even until the late 1930s, the Jewish community's response was confined to the publication of a few booklets and articles in the local Jewish press, as well as the distribution of posters and leaflets that carried warnings about the mission. Furthermore, Jewish society was itself divided. Orthodox Jews felt that the large Reform communities posed a far greater threat to them than did the small group of converted Jews. At the same time, the Reform Jewish leaders, who promoted liberal ideas and sought greater social integration, were reluctant to confront the powerful churches that sponsored the missions to the Jews (Sarna 1981; Eleff 2013). ${ }^{14}$

Notwithstanding his efforts to convert them, Cohn regarded himself as the protector of Jews. For example, in 1899 he asked the New York City Education Commissioner to remove from the curriculum books such as Walter Scott's Ivanhoe and Shakespeare's Merchant of Venice that portrayed Jews in a negative light. ${ }^{15}$ Two years later, he responded to the accusation that the Jews had refrained from waving flags to mark the inauguration of President Theodore Roosevelt following the assassination of his predecessor President 
William McKinley a couple days previously. He explained that the ceremony took place during Rosh Ha-Shana, the Jewish New Year, when all the Jews were at worship in the synagogues. ${ }^{16}$

With the rise of antisemitism in the early twentieth century, Cohn delivered countless sermons to the Christian public, reminding them of their historical debt toward their "older brothers." He pleaded with them to be more tolerant and not to offend, insult, or discriminate against the poor Jewish immigrants. ${ }^{17}$ Like many other evangelicals, Cohn regarded Zionism and the return of the Jews to the Land of Israel as a fulfillment of the Messianic prophecy of redemption. Cohn helped the Zionist movement by raising funds among Christians and encouraging them to purchase products produced in the Holy Land. ${ }^{18}$

In the early twentieth century, some members of Cohn's wife's family immigrated to the United States, and never having forgiven him for converting, they revealed publicly that Cohn's real name was Yosowitz and that he had never been ordained a rabbi. As this affair came to court, Cohn could no longer conceal some of the facts about his early life, and his lawyer admitted he was not really a rabbi (Bacon 1918, pp. 21-40). Witnesses also disclosed his real name to the court, forcing Cohn to tell his side of the story (Bacon 1918, pp. $40-50) \cdot{ }^{19}$

\section{Cohn's Rise and Downfall}

In 1906, Cohn used some of the money he collected to purchase a large farm and country house in Connecticut. ${ }^{20}$ A year later, he received a series of substantial donations amounting to some USD 100,000 from a wealthy woman named Francis Huntley (Bacon 1918, pp. 72-75). Cohn refused to share these donations with the Baptist church that had previously supported him. The church leaders accused him of violating his agreement with them and withdrew their sponsorship from Cohn's mission. Nevertheless, by virtue of this large endowment and his durable reputation, Cohn was able to maintain his operation and to raise funds independently (Ariel 2000, p. 30).

Cohn used the money to buy a plot in the heart of Williamsburg on which he erected his own building, which was completed a few years later. Named The House of the Prince of Peace, the building served as the mission's headquarters and activity center. In addition, he set up another missionary station on Coney Island, where many Jews spent their summer vacation. $^{21}$

Of all Leopold's children, Joseph was the only one to follow in his father's footsteps and embark on a career as a Christian clergyman..$^{22}$ In 1908, Joseph was ordained a pastor and began to participate in the mission's activities, which evolved into a family business. Unlike his father, who spoke with a heavy Hungarian accent, Joseph was practically a native English speaker, having arrived in the United States as a young child. This served him well in his many meetings with Christian communities across the country (Cohn-Hoffman 1953). ${ }^{23}$

On these trips, Joseph delivered countless sermons to his Christian audiences describing his father's missionary activities and appealing for their donations and support. Like his father, Joseph regarded himself a protector of the Jews and spoke out against those who slandered and discriminated them. He, likewise, described the many ways in which Jews contributed to the world in general and to the United States in particular. ${ }^{24}$

In 1908, Leopold became involved in a confrontation with Philip Spivak and David Shapiro, two converted Jews who ran a mission in Brooklyn. Seeking to undermine his credibility, the two men visited the country house he had recently bought in Connecticut. Leopold had claimed that the farm was part of his missionary institutions, and the two sought to establish that it was used only by the family. Upon their arrival, they confronted Joshua, Cohn's third son, who pulled a gun on them. The controversy between the three converted Jews was picked up by the local newspapers. In the ensuing years, the press 
reported extensively on the war of words that was waged both on the streets and in the courts (Bacon 1918, pp. 18-20, 60). ${ }^{25}$

Cohn fell into further disrepute following his wife's death in 1908 (Cohn 1996, pp. 47-50). ${ }^{26}$ Soon thereafter he married Edith, thirty-two years his junior, explaining that his sole reason for doing so was her willingness to raise his little son David. By that time, it was common knowledge that Cohn had become a wealthy man and personally owned some of the mission's properties (Bacon 1918, pp. 69-72).

Hoping to restore his tarnished public image, Cohn published his autobiography titled The Story of a Modern Missionary to an Ancient People - The Autobiography of Leopold Cohn, a Missionary Among the Two Million Jews of Greater New York. In subsequent editions, he toned down this bombastic claim and noted that he preached "only" to the 250,000 Jews of Brooklyn (Cohn 1908a, 1908b). Although the book is still highly regarded by today's messianic movements, the many historical testimonies, some of which were mentioned in this article, suggest that Cohn used his autobiography to whitewash his dubious past and to establish himself as a man of integrity whose only motivation was the spreading of the true word of God in the world.

In 1913, Cohn became entangled in a further legal affair, this time with Alexander Neuowich, a Hungarian Jew who came to the United States in 1902. Shortly after his arrival he converted; Cohn took him under his wing and in 1906 he became a missionary in Pittsburgh. A few years later, Neuowich became involved in some controversial business dealings and was forced to leave his office. He returned to New York, where Cohn again assisted him.

A few years later, several women claimed that following his wife's death Cohn had promised to marry them but had subsequently reneged. Upon learning of their complaints, Neuowich demanded that Cohn compensate them for breach of promise, and even threatened to sue him. Cohn reported a conspiracy against him to the police, as a result of which Neuowich was arrested.

In May 1913, Neuowich filed a suit against Cohn for wrongful imprisonment, claiming that as a result of Cohn's false accusation he had lost his employment and incurred additional expenses. Seeking to undermine Cohn's credibility, Neuowich's lawyer Alexander Bacon produced several witnesses who testified that Cohn's real surname was indeed Yosowitz and that he had never been ordained as a rabbi but was a simple innkeeper. They also exposed his involvement in the forging of the deed documents and his escape from Hungary before standing trial. A year later, Cohn was brought to trial for forging his immigration declaration and a 5 Dollar prize was offered to witnesses who would shed light on his real identity. ${ }^{27}$

In 1915, Samuel Freuder published an autobiography titled A Missionary's Return to Judaism (Freuder 1915). Freuder, too, was a former Hungarian Orthodox Jew who had studied at Pressburg Yeshiva. After his arrival in America, he was ordained a rabbi by the Reform Judaism's rabbinical seminary-the Hebrew Union College of Cincinnati (Evan Kaplan 1998). In 1891, he was baptized by the Chicago Hebrew Mission and became a missionary himself. A couple of years later, he repented and returned to Judaism. In his book, he devoted an entire chapter to Leopold Cohn, in which he gives an account of his false identity and the various scandals in which he was involved (Freuder 1915, pp. 164-77).

These revelations drove the church to set up its own special investigation committee, which published its report in 1916. The committee absolved Cohn of all guilt and encouraged Christians to continue to contribute to his missionary activities (Ariel 2000, pp. 33-34). ${ }^{28}$ Although Cohn was acquitted, his reputation was badly damaged and the newspapers continued to criticize him. ${ }^{29}$ In 1918, Philip Spivak sued Cohn for slandering him during the trial. The judge ruled in Spivak's favor, and although he only awarded him 1 Dollar as compensation, Cohn's reputation was tarnished once again. ${ }^{30}$

In 1918, Alexander Bacon, a former colonel who was Neuowich's lawyer, published a book titled The Strange Case of Doctor Cohn and Mister Yosovitz, adding sarcastically-with an Apology to Doctor Jekyll and Mister Hyde, a reference to Robert Louis Stevenson's famous 
book (Bacon 1918). Based on the court hearings and records, Bacon's book reviewed the facts that had come to light in recent years and accused Cohn of hiding the truth from his followers and acting in a dishonest manner. Cohn capitulated under the pressure, and in 1920 he resigned his post as head of the mission and was succeeded by his son Joseph.

\section{Away from the Public Eye}

Groomed by his father for over ten years, Joseph was well positioned to run the mission, having grown up in the United States and becoming familiar with the American lifestyle and mentality. Father and son divided the work between them: Leopold, who had the advantage of speaking Yiddish and possessing an extraordinary knowledge of Jewish texts, now took charge of all the mission's "Jewish issues". Joseph, on the other hand, expanded the mission's reach into other Christian communities and in 1924 he renamed it the American Board of Missions to the Jews, suggesting the national rather than the local nature of the operation.

In 1920, Leopold began to write, edit, and publish another monthly journal titled Shepherd of Israel. Unlike The Chosen People, which was aimed at the mission's Christian supporters, the Shepherd of Israel, which was written in both Yiddish and in English, targeted the Jewish audience. The journal sought to attract its readers' attention by publishing articles on various Jewish-related issues such as the Balfour Declaration, which promised the establishment of a "national home" for the Jews in Palestine; the appointment of a Jew, Lord Herbert Samuel, as the first British high commissioner of Palestine; and even the international convention of Agudat Israel, the ultra-Orthodox Jewish movement, in Vienna in $1923 .{ }^{31}$

The monthly also dealt with local issues of interest to the Jewish community, such as the "suicide epidemic" among Jews, the 1920s new immigration bills that limited the number of newcomers from Eastern Europe, and the activities of the Ku Klux Klan. ${ }^{32}$ In the 1930s, Cohn dedicated more articles to questions regarding Zionism and to Britain's newly issued White Paper, which curbed some of the rights that Jews had hitherto enjoyed in Palestine. ${ }^{33}$ Each of the issues showcased a certain "illustrious Jew" who had converted to Christianity, and some dealt with what the journal perceived to be persecution of Christian Jews by Jewish leaders and the Jewish press. ${ }^{34}$

Leopold furthermore published several new booklets titled: To the Two Houses of Israel (referring to the Orthodox and Reform movements); Cain and Abel-Israel and the Messiah; Jewish Holidays and their Meaning; Do Christians Believe in Three Gods?; and A Debate Between a Jew and a Christian. He also issued new editions of the books he had published in the past (Cohn 1911a, 1911b; Cohn [192?a], [192?b], [192?c], [192?d]; Cohn [193?a], [193?b], [193?c], [193?d]). By this time, the mission offered some ten publications for Jews and another ten, including one titled How to Destroy the Jews, for Christians (Van Gilder 1930). ${ }^{35}$

In 1930, as an expression of appreciation for his lifelong missionary work, Leopold Cohn was awarded an honorary doctorate by the Evangelical Wheaton College of Illinois (Ariel 2000, pp. 33-34). ${ }^{36}$ That same year, Cohn publicly attacked the fundamentalist pastor William Bell Riley for his antisemitic talks about a global Jewish conspiracy. In 1931, after spending three years in hospital, David, Leopold's youngest son, died. ${ }^{37}$

Joseph expanded the mission's outreach, and by 1932 he had opened branches in Philadelphia, Atlantic City, and Pittsburgh, as well as a branch in Lithuania (Glaser et al. 2021, pp. 171-215). ${ }^{38}$ By 1934, branches were operating in Jerusalem, Palestine, as well as in the Ukraine and Poland. ${ }^{39}$ Leopold Cohn died at the end of 1937 at the age of $75 .{ }^{40}$ The mission that he founded flourished under the management of his son Joseph, and by 1945 was operating several branches in the United States, as well as in Poland, Germany, Australia, France, Latvia, and Jerusalem. ${ }^{41}$ Joseph continued to develop the organization until his death in 1953, establishing further branches both in America and abroad.

After seventy years under the leadership of the Cohn family, the mission's management was transferred to people outside the family. These included Harry Pertlove, Daniel 
Fuchs, and Harold Sevener, and the current president is Dr. Mitch Glaser. Today, over 125 years after it was founded, the Chosen People Ministry operates in many countries and caters to hundreds of thousands of people, including many Jews. Cohn's remarkable success along with other social trends in the United States contributed to the dissemination of the idea of Messianic Judaism (Mart 2004; Ariel 2021).

One of the most popular messianic movements, Jews for Jesus, was established by Moishe Rosen. He worked for the American Board of Missions to the Jews, formerly the Chosen People mission, for seventeen years, where he studied the principles of Messianic Judaism. In 1970, he resigned and opened his own mission, which was initially called Hineni (Hebrew: here I am), and then Jews for Jesus (Rosen 2012). Today, dozens of messianic movements that have millions of supporters operate all over the world, and most of them have branches in Israel (Kjaer-Hansen and Skjott 1999).

\section{Cohn and the Founding of Contemporary Messianic Judaism}

Despite his numerous shortcomings, Cohn was a man of outstanding capabilities. Like so many Jewish immigrants, he used whatever advantage he could gain to help fulfill the American dream of social and economic success. He was astute enough not to replicate the traditional missionary methods employed by most former Jews and Christians, and to promote Messianic Judaism (Ariel 2000, p. 9). This relatively new concept was introduced exactly at the time when many Christians in America adopted premillennialist Dispensationalism, which changed the way they conceived Jews.

This earned Cohn a unique status, especially among those who were convinced that Messianic Judaism, along with the fact that he was a former rabbi, would be more effective than the conventional missionary approach. Indeed, various sources indicate that Cohn's fundraising surpassed that of other missions to the Jews. Although in 1902 Cohn's mission was still trailing behind, a report from 1911 reveals that its annual income of more than USD 25,000 was far greater than that of all other missions to the Jews. In fact, the second largest mission, the more established and respected Chicago Hebrew Mission, raised less than half that amount, while most other missions raised a few thousand dollars at most (Tompson 1902, pp. 277-78; Dennis et al. 1911, pp. 74-75).

Cohn's financial and managerial talents need no further proof other than the fact that The Chosen People, the organization which he founded in the nineteenth century, continues to operate successfully to this day. This does not, however, obviate the need to assess the mission's actual achievements. Clearly, one of the mission's main purposes was not survival or financial success, but the conversion of Jews. In that sense, Cohn's achievements were pretty dismal.

Although he was very explicit about the ongoing activities of the mission, the names of his donors, and the sums they contributed, Cohn was less than forthcoming regarding the names and numbers of the Jews he managed to convert. In 1905, 11 years after the mission was founded, Cohn declared that throughout this period he had managed to convert 72 Jews. Based on the figures published in issues of the Chosen People magazine, by 1915, some twenty years after the mission's establishment, the total number of converts was estimated at less than 200 (Freuder 1915, p. 173).$^{42}$ Scrutiny of the magazine's later issues indicate that the annual number of reported converts ranged between ten and twenty. It appears that up until Leopold Cohn's death in 1937, his mission succeeded in converting a very modest figure of some 500 Jews. Given that during this forty-year period the mission would have targeted over a million of Brooklyn's Jews, this is a very disappointing outcome and goes some way to explain why Cohn failed to establish a congregation of Messianic Jews despite numerous attempts to do so (Ariel 2000, p. 33).

This, however, does not diminish his major achievement, which was to establish Messianic Judaism as the mainstream concept of American missions to the Jews. While this was not especially meaningful for Jews, who in any event regarded all believers in Jesus as heretics and traitors, its impact on Christians was significant. Messianic Judaism taught Christians that regardless of how eager they were for Jews to convert and accept Jesus, they 
should not discriminate against them but rather respect them and support the expression of their national identity in the form of Zionism. Christians were advised to put aside ingrained antisemitic hatred, which was not going to force any Jew to convert, especially in America, where freedom of religion was a paramount principle. Instead, Messianic Judaism encouraged them to respect and display compassion for the Jewish immigrants, for only such an act of love could reveal to them the virtues of Christianity.

\section{Conclusions}

Leopold Cohn is one of those Jews who, after living a very traditional and unambitious life in Europe, not only found a new calling in America but was exceptionally successful at it. Due to his unique position, halfway between a Jew and a Christian, Cohn did not gain full recognition from either camp. Christians, perhaps rightly so, were uneasy with the use of his office for his own and his family's enrichment, and with his ongoing legal tangles. Jews habitually looked askance at anyone aspiring to convert them, let alone someone claiming to be a former rabbi. Moreover, both Jewish and Christian leaders looked askance not only at Cohn's own doing but also at his attempt to merge the two religions, thus presenting Messianic Judaism as a form of religious syncretism.

It appears that both Jews and Christians failed to appreciate the magnitude of Cohn's contribution to furthering their interests. The benefits that Jews derived from Cohn's activity came rather early in his career. He greatly assisted the immigrant newcomers, helping them in many ways. Yet, his really significant contribution to the Jews was his work among the Christians. In countless sermons he delivered to them, he reiterated the same messages: that Jews were their older brothers, that they should be treated fairly, and that showing them kindness was the only Christian way to help them see the true light of Jesus. This message served to reduce the level of antisemitism among them.

From a Christian perspective, by promoting Messianic Judaism in America, Cohn supplied the missions to the Jews with a very sophisticated strategy for attracting Jews. Its outcome was perhaps felt less during Cohn's lifetime, when most Jews were poor and underprivileged, than during the second half of the twentieth century, when Jews, especially those residing in the large cities, joined the socio-economic elite. By then, Jews who no longer felt obligated to the Jewish religion but on the other hand did not wish to convert to Christianity, were offered the option of becoming Messianic Jews. This goes some way to explaining the great popularity of the Jews for Jesus movement, particularly in the last third of the twentieth century.

Moreover, Leopold Cohn and his son Joseph were among the first Christians to openly express their commitment to the Jewish people and to the Zionist idea. They spread these views among millions of Christian listeners, including thousands of clergymen. These audiences came to reject the centuries-old legacy of hate, which was the only tradition they knew, and to extend to the Jews their love and support. Leopold Cohn and his son were also among the first to prioritize Zionism, and later the State of Israel, in evangelical Christianity's scale of values. In their time, such pro-Jewish and pro-Zionist sentiments were extremely rare among Christians. Today, however, tens of millions of American evangelical Christians firmly support Israel in a manner that was unthinkable during the Cohns' time. Although this support is not motivated by Zionist ideology, but by pure Christian principles, and despite realizing that this favorable attitude is only limited until such time in the future when Jews would have to face the consequences of their heretical beliefs, still, this massive support allows Israel to be stronger, at least in America's public opinion and by its government (Spector 2009; Ariel 2013; Goldman 2018).

Funding: This research received no external funding.

Institutional Review Board Statement: Not applicable.

Informed Consent Statement: Not applicable. 
Data Availability Statement: Not applicable.

Conflicts of Interest: The author declares no conflict of interest.

\section{Notes}

"Statistic of the Jews; Jewish population of the world," American Jewish Yearbook (1920-1921), p. 368.

On the Jewish life in Maramaros county see: Keren-Kratz (2015).

The Shepherd of Israel, May 1926. On this community see: Steinberger (2005).

Brooklyn Daily Eagle, 10 April 1887, p. 10.

The Chosen People, March 1897, pp. 6-7.

Hebrew Standard, 13 October 1893, p. 6.

A full analysis of Cohn's missionary strategy and comparing it to that of other missions, both in the past and during his lifetime, is beyond the scope of this article. For an extensive discussion on these issues see: Rambo (1993).

Chosen People, December 1896, p. 8; ibid., May 1897, p. 7; ibid., March 1899, p. 7. On the garment industry see Goldstein and Greenberg (2012).

For example: The Chosen People, January 1902, p. 2.

Chosen People, February 1897, p. 1; ibid., May 1897, p. 8.

Brooklyn Daily Eagle, August 31, 1906, p. 4; ibid., February 10, 1899, p. 11; ibid., February 9, 1900, p. 13; idem., 23 June 1900 , p. 13. Chosen People, January 1898, p. 7; ibid., March 1899, p. 7; ibid., January 1901, p. 4.

Chosen People, November 1900, p. 1; Yidishes Togblat, 27 April 1909, p. 4; Morgen Journal, 30 May 1909, p. 8; ibid., 23 October 1910, p. 4; ibid., 31 August 1916, p. 4; ibid., 3 September 1916, p. 6; Di Varheit, 30 September 1911, p. 8; ibid., 25 November 1913 , p. 5. Chosen People, January 1898, pp. 3-4; ibid., January 1899, p. 4-5; Di Varheit, 12 January 1913, p. 7.

Brooklyn Daily Eagle, 7 January 1899, p. 14.

Brooklyn Daily Eagle, 24 September 1901, p. 16; Chosen People, October 1901, p. 2.

Chosen People, October 1902, p. 3; ibid., November 1902, p. 1; ibid., February 1904, p. 4; Brooklyn Daily Eagle, February 19, 1902, p. 12; ibid., 21 February 1902, p. 6; ibid., 5 May 1902, p. 12; ibid., 7 May 1902, p. 3; ibid., 24 December 1906, p. 11; ibid., 18 February 1907, p. 21; ibid., 9 December 1907, p. 10.

Chosen People, December 1915, p. 1.

Ibid., December 1899, p. 4; ibid., January 1902, p. 3.

Ibid., November 1906, p. 6; ibid., December 1906, p. 1; ibid., November 1907, p. 7.

Ibid., February 1908, p. 6-7; ibid., December 1908, p. 7; ibid., October 1909, pp. 3-4.

Ibid., February 1902, p. 8; ibid., March 1906, p. 1.

Brooklyn Daily Eagle, 7 June 1909, p. 14; ibid., 29 September 1911, p. 3.

Ibid., March 2, 1912, p. 10; Pokeepsie Evening Enterprise, May 25, 1914, p. 6; Bolivar Breese, 17 September 1914 , p. 1.

Brooklyn Daily Eagle, 5 July 1908, p. 6; ibid., 21 August 1901, p. 7; ibid., 3 January 1909, p. 2; ibid., 8 October 1913, p. 1; ibid., 15 December 1913, p. 11; Di Varheit, 6 July 1908, p. 2.

Brooklyn Daily Eagle, 6 April 1908, p. 22.

Di Varheit, 11 October 1914, p. 3.

(Pierson 1916); Brooklyn Daily Eagle, 15 May 1916, p. 2; ibid., June 16, 1916, p. 4; ibid., 22 September 1916, p. 20.

Brooklyn Daily Eagle, 19 February 1917, p. 1; ibid., 21 February 1917, p. 3; ibid., 22 February 1917, p. 14; ibid., 24 February 1917 , p. 15.

Brooklyn Daily Eagle, 7 May 1918, p. 2; ibid., 13 May 1918, p. 1.

The Shepherd of Israel, December 1921; ibid., November 1922; ibid., November 1923.

Ibid., April 1922; ibid., October 1922; ibid., December 1923.

Ibid., July-August 1930; ibid., September 1930; ibid., December 1930; ibid., January 1931.

Ibid., May 1923; ibid., July 1923; ibid., June 1926; ibid., November 1926.

The Chosen people, April 1930, p. 2.

Wheaton College: Honorary Degrees (http:/ / a2z.my.wheaton.edu/honorary-degrees), retrieved 10 December 2021.

Brooklyn Daily Eagle, 11 November 1931, p. 3; ibid., 12 November 1931, p. 19; ibid., 13 November 1931, p. 21.

The Shepherd of Israel, March 1932; The Chosen People, December 1932, p. 11.

The Chosen People, February 1934, p. 2; ibid., March 1935, p. 2.

Brooklyn Daily Eagle, 20 December 1937, p. 20. 
Ibid., 27 October 1945, p. 5; ibid., 28 October 1945, p. 30.

The Chosen People, May 1905, p. 8.

\section{References}

Ådna, Jostein, and Hans Kvalbein, eds. 2000. The Mission of the Early Church to Jews and Gentiles. Tübingen: Mohr Siebeck.

Ariel, Yaakov. 2000. Evangelizing the Chosen People: Missions to the Jews in America, 1880-2000. Chapel Hill: University of North Carolina Press.

Ariel, Yaakov. 2004. Migration and conversion: Jewish converts to Christianity in America at the turn of the 20th century. Jahrbuch des Simon Dubnow Instituts 3: 71-87.

Ariel, Yaakov. 2013. An Unusual Relationship: Evangelical Christians and Jews. New York: New York University Press.

Ariel, Yaakov. 2021. Chosen People Ministries and its place within the larger context of Evangelical missions to the Jews. In A Rabbi's Vision Continues: In Celebration of the 125th Anniversary of Chosen People Ministries. Edited by Mitch Glaser, Gregory Hagg and Alan Shore. New York: Chosen People Ministries, pp. 171-230.

Bacon, Alexander. 1918. The Strange Story of Dr. Cohn and Mr. Joszovics (with Apologies to "Dr. Jekyl and Mr. Hyde"). New York: Colonel Alexander S. Bacon.

Brog, David, and John Hagee. 2006. Standing with Israel: Why Christians Support Israel. Lake Mary: FrontLine.

Cohn, Leopold. 1896. Mah Shemo U-Mah Shem Beno. Brooklyn: Louis Zaltzman Press (Yiddish).

Cohn, Leopold. 1898a. Behold the Virgin Shall Conceive and Bear a Son. Brooklyn: American Board of Missions to the Jews.

Cohn, Leopold. 1898b. Messiah Be Cut Off. Brooklyn: Life Line Mission.

Cohn, Leopold. 1908a. The Story of a Modern Missionary to an Ancient People: The Autobiography of Leopold Cohn, Missionary among the 2,000,000 Jews of Greater New York. New York: Chosen People.

Cohn, Leopold. 1908b. The Story of a Modern Missionary to an Ancient People: Being the Autobiography of Leopold Cohn, Missionary to the 250,000 Jews of Brooklyn. Brooklyn: Chosen People.

Cohn, Leopold. 1911a. Cain and Abel Israel and the Messiah. Brooklyn: Contributed for distribution by the Life Line Mission.

Cohn, Leopold. 1911b. To Both the Houses of Israel: Orthodox and Reformed Judaism. Brooklyn: Beth Sar Shalom.

Cohn, Leopold. 192?a. Behold the Virgin. New York: American Board of Missions to the Jews, Inc.

Cohn, Leopold. 192?b. The Meaning of the Jewish Holy Days: Jewish Feasts and Fasts, Their Symbolism in Type and Fulfillment. New York: American Board of Missions to the Jews, Inc.

Cohn, Leopold. 192?c. Yidishe Yamim Tovim Un Zeyer Bedeytung. Brooklyn: Williamsburg Mission to the Jews, (Yiddish).

Cohn, Leopold. 192?d. Messiah Shall be Cut Off. New York: American Board of Missions to the Jews, Inc.

Cohn, Leopold. 193?a. A Dialogue between a Jew and a Christian. Brooklyn: American Board of Missions to the Jews.

Cohn, Leopold. 193?b. Cain and Abel, or, Israel and the Messiah. Brooklyn: American Board of Missions to the Jews.

Cohn, Leopold. 193?c. The Trinity in the Old Testament or, Do Christians Worship Three Gods? Brooklyn: American Board of Missions to the Jews.

Cohn, Leopold. 193?d. Fun Vemen Redt Yeshaya 53? Brooklyn: American Board of Missions to the Jews (Yiddish).

Cohn, Leopold. 1996. To an Ancient People: The Autobiography of Dr. Leopold Cohn. New York: Chosen People Ministries.

Cohn-Hoffman, Joseph. 1953. I Have Fought a Good Fight: The Story of Jewish Mission Pioneering in America. New York: American Board of Missions to the Jews.

Cohn-Sherbok, Dan. 2000. Messianic Judaism. London: Cassell.

Dennis, James Shepard, Harlan Page Beach, Charles Harvey Fahs, and John George Bartholomew, eds. 1911. World Atlas of Christian Missions. New York: Student Volunteer Movement for Foreign Missions.

Douglas, Catherine. 1894. Hermann Warszawiak: The Little Messianic Prophet, Or Two Years' Labour Among the Refugee Jews in New York. Edinburgh: A. Elliot.

Eleff, Zev. 2013. The Baptism of Four Little Roxbury Girls: Jewish Angst in America's Religious Marketplace During the Interwar Period. American Jewish Archives Journal 65: 73-94.

Evan Kaplan, Dana. 1998. Rabbi Samuel Freuder as a Christian Missionary: American Protestant Premillennialism and an Apostate Returner, 1891-1924. American Jewish Archives Journal 50: 41-74.

Freshman, Charles. 1868. The Autobiography of the Rev. Charles Freshman: Late Rabbi of the Jewish Synagogue at Quebec, and Graduate of The Jewish Theological Seminary at Prague. Toronto: Samuel Rose, Wesleyan Book Room.

Freuder, Samuel. 1915. A Missionary's Return to Judaism: The Truth about the Christian Missions to the Jews. New York: The Sinai Publishing Company.

Gidney, William Thomas. 1908. The History of the London Society for Promoting Christianity Amongst the Jews: From 1809 to 1908. London: London Society for Promoting Christianity Amongst the Jews.

Glaser, Mitch, Gregory Hagg, and Alan Shore, eds. 2021. A Rabbi's Vision Continues: In Celebration of the 125th Anniversary of Chosen People Ministries. New York: Chosen People Ministries.

Goldman, Samuel. 2018. God's Country: Christian Zionism in America. Philadelphia: University of Pennsylvania Press.

Goldstein, Gabriel, and Elizabeth E. Greenberg. 2012. Sewn together: The garment industry and American Jewry. In A Perfect Fit: The Garment Industry and American Jewry, 1860-1960. Edited by Gabriel M. Goldstein and Elizabeth E. Greenberg. Lubbock: Yeshiva University Museum and Texas Tech University Press, pp. 3-17. 
Gross, Shlomo Yaacov, and Yitzhak Yosef Cohen. 1983. Sefer Marmarosh. Tel Aviv: Beit Marmoresh.

Ice, Thomas D. 2009. What Is Dispensationalism? Article Archives. p. 71. Available online: https://digitalcommons.liberty. edu/pretrib_arch/71?utm_source=digitalcommons.liberty.edu\%2Fpretrib_arch\%2F71\&utm_medium=PDF\&utm_campaign= PDFCoverPages. (accessed on 10 December 2021).

Keren-Kratz, Menachem. 2015. Marmaros, Hungary-The Cradle of Extreme Orthodoxy. Modern Judaism 35: 147-174. [CrossRef]

Keren-Kratz, Menachem. 2021. Jewish education in Maramaros county (Hungary, Romania, Czechoslovakia). Dor Le-Dor 55: 183-199. (In Hebrew)

Kjaer-Hansen, Kai, and Bodil F. Skjott. 1999. Facts \& Myths About the Messianic Congregations in Israel 1998-1999. Jerusalem: United Christian Council in Israel.

Mart, Michelle. 2004. The 'Christianization' of Israel and Jews in 1950s America. Religion and American Culture 14: 109-147. [CrossRef]

Mégier, Elisabeth. 2008. Jewish converts in the Early Church and Latin Christian exegetes of Isaiah, c. 400-1150. Journal of Ecclesiastical History 59: 1-28. [CrossRef]

Meyer, Louis. 1983. Eminent Hebrew Christians of the Nineteenth Century: Brief Biographical Sketches. Lewiston: Edwin Mellen Press.

Nerel, Gershon. 1996. Messianic Jews in Eretz-Israel. Ph.D. dissertation, The Hebrew University, Jerusalem, Israel.

Pierson, Delavan Leonard, ed. 1916. The Missionary Review of the World. New York: Missionary Review Publishing Company, Incorporated, vol, 39, p. 873.

Pollack, Benjamin. 2013. Reassessing 'A Walker in the City': Alfred Kazin's Brownsville and the Image of Immigrant New York. American Jewish History 97: 391-411. [CrossRef]

Popkin, Richard H. 1994. Christian Jews and Jewish Christians in the 17th century. In Jewish Christians and Christian Jews: from the Renaissance to the Enlightenment. Edited by Richard H. Popkin and Gordon M. Weiner. Dordrecht: Kluwer Academic Publishers, pp. 57-72.

Rambo, Lewis R. 1993. Understanding Religious Conversion. New Haven: Yale University Press.

Rausch, David A. 1983. Arno C. Gaebelein, 1861-1945: Irenic Fundamentalist and Scholar. Lewiston: E. Mellen Press, p. 1945.

Rosen, Ruth. 2012. Called to Controversy: The Unlikely Story of Moishe Rosen and the Founding of Jews for Jesus. Nashville: Thomas Nelson.

Sarna, Jonathan D. 1980. From Necessity to Virtue: The Hebrew-Christianity of Gideon R. Lederer. Iliff Review 37: 27-33.

Sarna, Jonathan D. 1981. The American Jewish Response to Nineteenth Century Christian Missions. Journal of American History 68: 35-51. [CrossRef]

Sobel, Bernard Zvi. 1974. Hebrew Christianity: The Thirteenth Tribe. New York: John Wiley \& Sons.

Spector, Stephen. 2009. Evangelicals and Israel: The Story of American Christian Zionism. New York: Oxford University Press.

Steinberger, Chaim. 2005. First Hungarian Congregation Ohab Zedek: Founded in 1873. New York: First Hungarian Congregation Ohab Zedek.

Stratton, Kimberly B., and Andrea Lieber, eds. 2016. Crossing Boundaries in Early Judaism and Christianity: Ambiguities, Complexities, and Half-Forgotten Adversaries. Boston: Brill.

Tompson, Albert Edward. 1902. A Century of Jewish Missions. Chicago, New York and Toronto: Fleming H. Revell Company.

Van Gilder, Heber Osborne. 1930. How to Destroy the Jews: Sermon Preached by H. O. Van Gilder, Pastor of Central Baptist Church, Columbus, Ohio, to His Own Congregation on July 27, 1924. Brooklyn: American Board of Missions to the Jews. 